\title{
Some Thoughts About Natural Law
}

\author{
Phillip E. Johnson $\dagger$
}

My first task is to define the subject. When I use the term "natural" law, I am distimguishing the category from other kinds of law such as positive law, divine law, or scientific law. When we discuss positive law, we look to materials like legislation, judicial opinions, and scholarly analysis of these materials. If we speak of divine law, we ask if there are any knowable commands from God. If we look for scientific law, we conduct experiments, or make observations and calculations, $\dot{\mathrm{m}}$ order to come to objectively verifiable knowledge about the material world.

Natural law-as I will be using the term in this essay-refers to a method that we employ to judge what the principles of individual morality or positive law ought to be. The natural law philosopher aspires to make these judgments on the basis of reason and human nature without mvoking divine revelation or prophetic inspiration. Natural law so defined is a category much broader than any particular theory of natural law. One can beheve in the existence of natural law without agreeing with the particular systems of natural law advocates like Aristotle or Aquimas. I ain describing a way of thinking, not a particular theory.

In the broad sense in which I am using the term, therefore, anyone who attempts to found concepts of justice upon reason and human nature engages in natural law philosophy. Contemporary philosophical systems based on feminism, wealth maximization, neutral conversation, liberal equality, or hibertariamsm are natural law philosophies. They start with assumptions about human nature and what is good for people, and they clain to employ reason to judge the relative justice or injustice of legal practices hike slavery, the free market, patriarchy, and socialism. Like the man who was astomshed to find that he had been speaking in prose all his life, we who make it our business to resolve differences about questions of morahty and justice through the use of reason are surprised to find that we are expounding natural law.

Next I should explain what I mean by reason, an ability available in theory to all lumanity, however warped it may be im particular individuals or groups. Reason consists of two components: logic and clearheaded perception of reality. The rational mind must possess both qualities. For example, some paranoids have an impressive ability to think

$\dagger$ Professor of Law, Boalt Hall School of Law, University of California, Berkeley. A.B. 1961, Harvard University; J.D. 1965, University of Chicago. 
logically, and they may obtain a high score on the Law School Aptitude Test. Their thinking is not rational, however, because it proceeds from a fundamental misperception of reality. They imagine that the rest of the world is persecuting them. The paranoid's mind is like a fast ship speeding along a fog-bound coastline without any navigational equipinent. The engines may be running well, and the steering gear may be in excellent order, but the captain has no idea where she is going, and the ship will surely run on the rocks. We all know people who are brilliant in a sense, but have a screw loose. They can think, but they are not rational because they lack clear-headed perception.

In contrast with the brilliant paranoid there is the uneducated but crafty peasant, who has impressive common sense in dealing with the ordinary problems of traditional village life, but who is absolutely baffled by changed circumstances or unfamiliar problems. He has an acute grasp of the reality he has always known, but no grasp at all of the abstractions that are so real to educated people in cities. His perceptions are clear-headed, but his reasoning equipment is undeveloped.

Natural law reasoning, then, is the method by which persons gifted with both clear-headed perception and logical analytic ability can reason together about the values that ought to be the basis of law and normative judginents about individual behavior. Natural law reasoning, like all reasoning, has to proceed from axioms or presuppositions that are not themselves derived from logic. Natural law thinkers must identify basic values (like hiberty, or equality, or knowledge, or commumity) that are self-evidently good, or at least intuitively attractive. They also have to assume or discover that huinan nature has certain innate characteristics. For example, they may assert that men and woinen either do or do not have different priorities as between family life and careers. They may assume that people are predominantly rational pursuers of self-interest, or they may claim to have discovered that they are controlled by powerful unconscious impulses or malevolent social structures. They inay posit unlimited opportunity as the greatest good, or argue on the contrary that rational people would rather have a fair amount of security to protect theinselves from misfortune or improvidence.

If agreement at this basic level cannot be reached, then reasoning can proceed no further. If agreement on basic principles and factual assumptions can be achieved, then reasonable people reasoning together eventually can reach agreement on other primciples and arrangeinents that follow logically froin the basic ones. (The validity of logical reasoning as a means of reaching truthful conclusions is, of course, one of the inost important of the self-evident assumptions on which the entire enterprise rests.) It is unlikely that detailed conclusions will einerge from this reasoining process, however. Probably, natural law reasoning will pro- 
vide at best only general principles of justice, principles that are arguably consistent with a variety of specific legal rules.

Natural law is a discredited concept in the eyes of many sophisticated people today because we hive in an age dominated by relativistic and skeptical habits of thought. The examples I have given illustrate that statements about human nature and about what people ought to want are highly controversial. Conceding this point is not fatal to the natural law enterprise, however. After all, there is endless controversy over the basic principles of tort and contract, and there is no consensus about the purpose of criminal punishment. It is true that there are rival opinions about natural law, and we cannot agree on their validity, but this does not prove that the enterprise is futile or even avoidable.

We can no more abandon natural law reasoning than we can stop speaking in prose. We are all constantly inaking moral judgments based on iniphicit views of hunian nature, such as whether inan is naturally acquisitive or cooperative, and whether the domination of one group by another is a natural reflection of inequality or an artificial interference with natural equality. We suppose that Puritanisin produces hypocrisy because it conflicts with the irrepressible desire for pleasure, and that free market incentives produce wealth because they take advantage of the natural desire to iniprove one's economic condition. We presune that additional wealth is good because people can use it wisely to further their own goals, or bad (m excess) because it leads to pointless luxury, envy, and corruption.

So we do engage in natural law reasoning despite the prevailing climate of skepticism. That chmate does strongly influence low we engage in this reasoning, however. The embarrassment of asserting supposedly self-evident principles in an intellectual atmosphere in which everything is automatically called into question inakes us try to get by on as few such principles as possible-lience the prevalence in our day of natural law systems that are based on a single governing concept: econonric efficiency, equality, neutrality, autonomy (neutral conversation), or utility. If the only self-evident proposition we liave to assert is that pleasure is preferable to pain, for example, we have started the ball rolling with minnnal risk of a serious debate over fundamental principles. This is inuch easier than having to defend at the very outset a series of propositions about human nature and what is good for men and women.

A second characteristic of conteinporary natural law philosophies is that they are legahistic. The ain of our philosophers is to develop rules of law capable of producing justice. Expectations in this respect are high. For example, the single concept of "equality," which some have asserted 
to be an empty idea, ${ }^{1}$ is employed by a master like Ronald Dworkin to resolve all sorts of thorny "hard cases" that divide contemporary courts. ${ }^{2}$ In the hands of another master, Richard Posner, the single goal of wealth maximization appears capable of generating answers to most of the legal controversies of the modern world, and the ancient world as well. ${ }^{3}$

But the ambition in developing legal rules from exceedingly simple principles is matched by a corresponding modesty in addressing the individual person who is to hive under those rules. Earher natural law theorists talked about what is good for man, what are the appropriate goals of life, and so on. Contemporary liberal theorists see the individual as somebody who does basically whatever he happens to want to do, provided that he obeys the laws. We do not have much to say about what the individual is supposed to want to do, because any discussion of that point would be almost by definition illiberal. What people want to do is their own busmess, and each person is a sovereign in the kingdom of ends. Theory does no more than provide the rules that enable these sovereigns to avoid war.

This lack of concern about individual morahty creates problems that threaten to underınine the enterprise. First, it is possible that the pursuit of a certain value by individuals may be inconsistent with the realization of that value by the society as a whole. If utility is our goal, for example, we want to maximize happiness and minimize misery in the society as a whole. The implication for the individual would seem to be that she should pursue pleasure and avoid misery in her own life. But what reason is there to suppose that a society of pleasure seekers will generate rules of conduct that produce the greatest good for the greatest nuinber? If we ask what traits of character are likely to produce universal happiness in the long run, we might very well conclude that the traits in question are ones unlikely to be furthered by the widespread acceptance of utilitarian philosophy, especially in the vulgarized form in which that philosophy is likely to be absorbed by the public. (Dostoyevski's Raskolnikov committed murder in furtherance of solid utilitarian principles. ${ }^{4}$ ) Sophisticated utilitarians have seen this problem and have sometimes suggested that achievement of utilitarian goals might require that the utilitarian principles governimg society be concealed from the public. $^{5}$ That possibility suggests the paradox that advocating utilitarian principles to the public may be antiutilitarian.

1. See Westen, The Empty Idea of Equality, 95 HARv. L. REv. 537 (1982).

2. See R. DWorkin, A Matter of Principle (1985).

3. See R. Posner, The ECONOMICS OF Justice (1981).

4. See generally F. Dostoyevski, CRime AND PUnishment (C. Garnett trans. 1950).

5. See Williams, A Critique of Utilitarianism, in UTILITARIanism: For AND AGainst 13840 (J. Smart \& B. Williams eds. 1973). 
There may be a similar problem if the social goal is wealth maximization. Would legislators who are inainly interested in maximizing their own wealth - or who are financed by capitalists with that motiveenact and enforce laws that maximize the wealth of the society as a whole? I can understand that a legislature made up of investors and speculators might be persuaded to endorse principles of free trade and competition for all if its members were convinced that attempts to gain special privileges for themselves would only lead to further exceptions for others, with consequent losses for everyone. But it seems to ine that economic actors are constantly faced with opportunities to make large shortrun profits for themselves, through activities that in the long run may create inefficiencies for society as a whole. "Let us eat, drink, and maximize wealth for the present," a vulgar follower of the economic literature might say, "for in the long run we will all have already taken out our profits."

These are not merely abstract possibilities. It is now orthodox to think that one of the most serious threats to American productivity is the pressure on managers to deliver impressive quarterly profit reports at the expense of long-range considerations.

It seeins likely that an efficient society needs the services and citizenship of a great inany individuals who love doing a good job for its own sake, and who would rather be honest than rich. But how are these familiar virtues of the "Protestant ethic" to be preserved if the pursuit of wealth is idealized as an adequate goal for individuals? Perhaps a governing cabal of wealth inaximizers ouglit to think about taxing the output of legal economists to subsidize the distribution of free copies of Pilgrim's Progress in the schools. It is, after all, people who read books of that sort who built the foundations of western capitalism.

I perceive a similar problein with philosophies that place a heavy emphasis on wealth redistribution, as do the theories of Rawls ${ }^{6}$ and Dworkin. ${ }^{7}$ These writers give the least gifted or least productive persons inportant rights against the society as a whole. Indeed, they seem to legitimate the claim that "the world owes ine a living." The rights are generous enough, but the obligation to pay runs against no one in particular. A prosperous liberal redistributionist can with perfect consistency argue both that the poor must be given their economic rights, and that the tax burden should be imposed upon others. A society based on sucl1 principles has what I call a inoral deficit, which inanifests itself concretely in budgetary deficits $w^{3}$ hen the obligation to pay benefits exceeds the willingness to pay taxes.

6. See J. Rawls, A Theory OF Justice (1971).

7. See R. Dworkin, supra note 2. 
One problem with legahistic natural law philosophies, then, is that they neglect the problem of the individual, even though it is these individuals who will have to pass and maintain the laws. On the other hand, the legalistic philosophies may have more to say by imphication about the kind of people we ought to be and the kinds of individual goals we ought to pursue than appears on the surface. They are not quite as neutral about what constitutes the good life as they seein.

Whenever we decide to favor one set of choices, we make it more difficult to choose other sets even if that is not our intention. Let me illustrate the point with the ambiguous achievements of feminism as my example. In the early years of what we then called Women's Liberation, a dozen or fifteen years ago, objectors frequently asked what was to become of the traditional housewife who didn't want to be a doctor or a congressperson. The answer that was almost always given, if my memory does not deceive me, was that women having that preference would remain free to indulge it. The aim of the inovement was to remove obstacles in the path of those women who wanted to pursue formerly masculime careers, not to put pressure on other women who preferred to stay at home with the children. Each was to have free choice.

By now the difficulty of that way of thinking should be apparent. Men also listened to what the feminists were saying (indeed, they had little choice), and inany of them concluded that women who were capable of earning a living ought to be expected to do so. Feminists were among those supporting reinoving the concept of fault from the divorce courts, a reform that reinoved most of the obstacles in the path of a inan who wanted to leave his wife to marry his secretary or the intellectually stimulating new associate in his law firm. More important than the legal change was the fact that the social stigma was greatly relaxed. Divorce could still be expensive, of course, but certain variants of the ideology of equality supported the idea that the lousewife should be expected to earn her own way after receiving alimony for only a few years during a period adequate for retraining.

After all these developinents, what is the position of a young woinan who wants to spend her life making a home and raising children with a husband providing the financial wherewithal? A one-incone family will fall behind a two-income family financially, and the price of housing reflects the ability to pay present in all those two-income marriages. In any event, the housewife cannot rely upon her husband to provide a lifetime of support because lie can get out of the obligation too easily if he changes his mind. Our young woman simply must make and keep herself einployable; any other course of action would be reckless. No inatter how much we fiddle with the law, divorce settlements are unlikely to 
become an adequate replacement for the security of a permanent marriage.

The point is broadly apphicable. Although we may sincerely mean to protect free choice, we cannot protect all choices equally. One set of choices will be cherished as the norm; the others tolerated as the exception. The distinction carries an implied ideological message that may not be consciously intended. The message is implied not only in the conclusions we draw, but also in the selection of the topics we consider worth discussing. Questions that are not on the table for discussion are impliedly not important to answer.

I think that the legal philosophers of today are making an implied statement about the content of the rational life that they may not mean to make, but one that is inherent in their inethod. They imply that the rational life is the life spent in pursuit of wealtl, or perliaps wealth combined witli leisure. This is true not only of the writers who exalt wealtli maximization as the supreme goal of social life, but also of those who are more concerned with the redistribution of wealth and power than witli its maximization. Whetlier one says that the important thing is to create the greatest amount of wealtli possible, or to distribute wliatever wealth there is more fairly, one is einphasizing that wealth is the inost important thing that there is, the thing that rational people most care about. I don't mean to suggest that all these writers really mean to be promoting the worship of Mammon; on the contrary, inost of thein would probably repudiate the idea quite strongly once it is stated explicitly. Nonetlieless, the concern with the creation or distribution of wealtli is so pervasive that the impression is left that everything else in life is less important.

This emphasis on wealtli is the necessary consequence of the simplifying assumptions that liberal philosopliy has to make in an age of skepticism and pluralism. People inust decide for themselves what ends they want to pursue; legal philosopliers consider only low these cliosen goals can be achieved and accommodated. What we can say is that whatever goal you may decide to pursue, whatever project gives your life its ineaning, you will probably find money necessary or at least convement for pursuing it. We concentrate on wealth because that is something that is useful for everyone, not because we mean to msist that having wealth is an end in itself. Nonetheless, this way of thinking leaves the impression that the desire for wealth (and its first cousm, power) is the only rational desire, and that everything else is a matter of arbitrary whim.

Of course I am not suggesting that wealth is unimportant, or that legal philosophers are wrong to take into account the obvious fact that people are concerned up to a point witl maximizing their own wealth and power. But something important is being left out. A society composed of people who are constantly obsessed witli wealth and power will 
never be a just society, no matter what rules are proposed to govern it. A just society is not a society of self-aggrandizing individuals who are restramed only by police and courts enforcing rules drafted by enlightened philosophers. Rather, a just society is a society composed of just individuals, individuals who practice justice because that is a virtue they think worth cultivating for its own sake.

What I am suggesting is that we nay be empliasizing the wrong question by regarding the rules of the game as the most inportant thing rather than the individuals who are expected to enact those rules, to enforce them, and to internalize their values. At soine point we have to go back to the individual. We have to ask what is the nature of the rational individual and the rational life, and what legal arrangements can help to produce and maintain a commumity of rational individuals. It will not do to reply that the formation of character is a matter for the cliurch, the liome, and the schools, and that legal philosophers are concerned with laws and not people. We are not going to have any laws unless people inake them, and something about our culture seems to be inaking it terribly difficult for the home, the churches, and the schools to do their job. Maybe the way we are thinking is part of the problem, or evidence of the problein.

Let me pause at this point to state some unoriginal and possibly platitudinous propositions about the rational life. It is good to develop and make constructive use of whatever talents we have, quite apart from the rewards to be obtained by doing so. It is good to be prosperous instead of poor, but the best prosperity is the kind that comes from doing an important job well for its own sake, without constantly worrying about the immediate rewards. If one is at all prosperous, it is good to be generous, and to accept cheerfully the obligation to contribute to the relief of the misfortune of others. If one has to accept charitable assistance it is good to be grateful and to make efforts to become self-supporting as soon as circumstances permit.

It is a good thing to take pride in one's craft, and if we make an excellent product it is praiseworthy to refuse to sell out to a conglomerate even if the price is tempting. It is better to be the kind of lawyer who solves probleins and smooths crises, rather than the kind who makes more money by having a genius for causmg trouble. It is good to make a living by satisfying people's rational needs rather than their irrational ones, so that even if it is perfectly legal to manage the advertising account of a cigarette coinpany, it is better to go into another kind of work. It is irrational to indulge one's impulses towards self-righteousness, vindictiveness, or envy.

I have used the words "good, better, and best" rather freely in the last two paragraphs, and you may well ask what I mean by them. The 
answer is quite simple. The qualities I have described are ones that the rational person will admire. He or she will want to be that kind of person, will want to seek out persons having those quahities for friendship and cooperative work, and above all will want to raise children so that they develop these qualities. Such qualities are equally good for the individual and for the community. A society filled with individuals possessing qualities like these will be wealthy, not because it places a particularly high value upon money, but because it values the things that produce both wealth and security over the long run.

If what I have said so far is not mistaken, it follows that those who aim for economic justice-whether they define it as efficiency or fair distribution-need to pay more attention to the motivations of individuals. The important thing is not to derive a coinplex set of legal rules from an underlying moral or economic principle, but to determine the human qualities that further economic justice and liberal freedom and the means by which these qualities inay be developed and preserved. Freedom is a good thing only for people who are capable of using it rationally, and a free society can be preserved only by rational people.

To forestall any misunderstanding, let ine emplasize that this statement is in no sense an authoritarian reaction against liberal freedom. John Stuart Mill, who has been called the saint of liberal rationalisin, said precisely the saine thing in the first cliapter of his essay "On Liberty," and he said it repeatedly and with emphasis. Consider the following pair of sentences:

Despotism is a legitimate mode of government in dealing with barbarians, provided the end be their improvement, and the means justified by actually effecting that end. Liberty, as a principle, has no application to any state of things anterior to the time when mankind have become capable of being improved by free and equal discussion. ${ }^{8}$

Mill optimistically overlooked the fact that a substantial percentage of the population of his own society did not meet his standard of rationality.

And what of our own society? Is the public gradually becoming more capable of rationality, througl the effects of education and cnltural influences? I leave the answer to you, but it seems to me that there is reason to be concerned.

As a number of acute social critics have observed, the freedom and prosperity that we are proud to liave achieved may be undermining the personal characteristics that allowed that freedom and prosperity to develop. At the saine time we have a growing underclass and drug subculture that we seein helpless to change. Our public educational system

8. J.S. Mill, On Liberty, in The Six Great Humanistic EsSays of John Stuart Mill 136 (1963). 
is a near disaster. The National Commission on Public Education headed by University of California President David Gardner chose an appropriate title for its report: "A Nation at Risk." 9 The report began by observing, "If an unfriendly foreign power had attempted to impose upon America the mediocre educational performance that exists today, we might well have viewed it as an act of war."10 There seems to be a little evidence of some recent improvement, but there is no evidence that the fundamental flaws that led to the precipitous decline have been corrected.

What to do about our alarming situation is beyond the scope of this essay and also beyond my powers of discernment (although I have a few ideas). My concern here is merely to focus attention on a problem that is far more important than our debates over the rules of law or the theory behind those rules. Where should we as individuals look for guidance about the goals we should be pursuing and the values we should be cultivating? How can parents and teachers maintain sufficient confidence in those goals and values to pass them on to the children under our care?

Perhaps these questions cannot be answered without resorting to extremely controversial sources of inspiration, such as religious belief. I am not prepared to concede that point yet, however. Questions about the individual virtues that will preserve liberal freedom and further economic justice are very much within the province of natural reason. So are the questions of method by which we determine how to encourage those virtues. Those questions are the ones we need to be asking.

9. See National Comm'n on Excellence in Educ., A Nation at Risk: The IMPERATIVE FOR EDUCATIONAL REFORM 5 (1983).

10. Id. 